\title{
INTERFERENSI BAHASA INDONESIA TERHADAP
}

\author{
BAHASA ARAB \\ (Analisis Interferensi dalam Pembelajaran Maharah al-Kalam)
}

\author{
Muhamad Arif Mustofa \\ Institut Agama Islam Negeri (IAIN) Curup \\ Jl. Dr. AK Gani No. 01, Curup, Dusun Curup, Curup Utara, \\ Kabupaten Rejang Lebong, Bengkulu 39119 \\ email:aripatmi@gmail.com
}

\begin{abstract}
Abstrak
Bahasa sebagai alat komunikasi sudah seharusnya dapat difahami oleh lawan bicara seseorang. Akan tetapi, terkadang bahasa asing yang dipelajari dan digunakan dalam berbicara itu memunculkan kekeliruan-kekeliruan, di antara kekeliruan tersebut dikarenakan adanya interferensi dari bahasa yang lebih dahulu dikuasai. Hal ini juga terjadi pada mahasiswa PBA, mereka berbicara dengan menggunakan bahasa Arab akan tetapi terkadang juga muncul unsur-unsur bahasa Indonesia di dalamnya. Oleh karena itu, tujuan penelitian ini dilakukan untuk menggali informasi tentang macam-macam interferensi yang terjadi, factor-faktor yang menyebabkan interferensi, dan solusi bagi interferensi itu sendiri. Penelitian ini adalah penelitian kualitatif deskriptif, dimana data yang dikumpulkan berupa kata-kata tertulis atau lisan dari orangorang yang menjadi subyek penelitian dan perilaku yang dapat diamati. Data penelitian dicari melalui observasi, wawancara, serta dokumentasi. Penelitian ini menghasilkan beberapa hal: pertama; Interferensi bahasa Indonesia terhadap berbicara bahasa Arab bagi mahasiswa PBA terdiri dari interferensi semantic, sintaksis, morfologi, leksikologi, dan fonologi, kedua; faktor yang meyebabkan terjadinya interensi tersebut yaitu: dominasi bahasa Indonesia, kurangnya kosa-kata bahasa Arab, dan kebiasaan bahasa Indonesia yang sangat melekat sehingga susah ditinggalkan.
\end{abstract}

Kata Kunci: Interferensi, Arab-Indonesia, dan Kemahiran Berbicara 


\section{A. Pendahuluan}

Bahasa Arab merupakan bahasa dunia yang sudah banyak dipelajari serta menjadi bahasa Internasional yang banyak dipakai di berbagai sumber literature. selain itu, bahasa Arab juga sering disebut mempunyai kepustakaan besar di semua bidang ilmu pengetahuan. ${ }^{1}$

Bahasa Arab sebagaiman kita ketahui merupakan bahasa Asing, sehingga pengajarnnya berbeda dengan pengajaran ilmu yang lain. Karena pengajaran bahasa tersebut mengutamakan beberapa keterampilan berbahasa, yaitu keterampilan menyimak (istima'), keterampilan berbicara (kalam), keterampilan membaca (qiro'ah), dan keterampilan menulis (kitabah).

Bahasa sebagai alat komunikasi tentu menjadi sangat penting. Komunikasi yang paling efektif adalah dengan berbicara. Bila hal ini dikaitkan dengan pembelajaran bahasa Arab, kemahiran berbicara merupakan salah satu tujuan yang harus dicapai dan dikuasai oleh peserta didik. Kemahiran berbicara merupakan kemampuan dalam mengucapkan bunyi atau kata-kata dalam menyampaikan ide, keinginan, perasaan terhadap lawan bicara. $^{2}$ Kita tidak akan tahu maksud dan keinginan seseorang sebelum seseorang menyampaikannya.

Ada beberapa hal yang menjadi menunjang kemampuan berbicara bahasa Arab seseorang dapat berkembang, pertama penguasaan mufradat, Kedua, keberanian untuk mengucapkan meskipun salah, keberanian ini harus dibentuk dengan pembiasaan sehingga menjadikan seseorang akan percaya diri dalamberbicara, Ketiga, teman atau lingkungan bahasa. Kedudukan bi'ah lughawiyah sangat membantu keberhasilan kalam. Karena kalam memmbutuhkan teman atau lawan bicara.

\footnotetext{
${ }^{1}$ Azhar Arsyad, Bahasa Arab dan Pengajarannya, Yogyakarta: Pustaka Pelajar, 2010,h. 11

${ }^{2}$ Moh. Matsna, HS, Problematika pengajaran Bahasa Arab di Indonesia dan Pemecahannya, Makalah Seminar Pertemuan Ilmiah Bahasa Arab II di UGM, 2001
} 
Pembelajaran kalam harus dilakukan secara terus menerus, tidak boleh belajar bahasa Arab khususnya kemahiran berbicara dilakukan hanya sesaat atau satu semester saja. Hal ini sejalan dengan apa yang disampaikan Ismail Sini dalam pengantar kitabnya

"Bahwasanya pembelajaran bahasa akan mengalami kemajuan apabila dilakukan secara terus menerus dan dipraktikkan dalam berkomunikasi antara seorang guru dengan siswanya begitu juga siswa dengan temantemannya yang secara tidak langsung akan membentuk lingkungan kebahasaan yang bagus dan akan mempersiapkan tempat lingkungan yang baik dan subur untuk bahasa serta membutuhkan waktu yang mencukupi."3

Kemahiran berbahasa bermacam-macam, ada yang berbentuk lisan dan tulisan. Ada yang bersifat reseptif (menyimak dan membaca) dan ada juga yang bersifat produktif (berbicara dan menulis). Kemahiran berbicara sebagai kemampuan yang bersifat produktif berfungsi sebagai penyampai dan penyebar informasi secara lisan ${ }^{4}$. Sebagai bentuk penggunaan bahasa, berbicara merupakan kegiatan berbahasa yang penting dalam kehidupan sehari-hari. Sebagaimana berbicara merupakan kegiatan yang bersifat aktif dan produktif, kemampuan berbicara menuntut penguasaan terhadap beberapa aspek dan kaidah penggunaan bahasa. ${ }^{5}$

Keterampilan berbicara adalah keterampilan yang terpenting dalam bebahasa, hal ini dikarenakan berbicara adalah bagian dari keterampilan yang

${ }^{3}$ Ismail Sini dkk,. al Arabiyah Li-Annasyiin, TP: Wizarotu Al-Maearif Mamlakah Al„Arabiyah As-sindiyahx, 2001

${ }^{4}$ Mohammad Ahsanuddin, Pengembangan Keterampilan Berbicara dan Menulis Dengan Media Yahoo Messenger, Bandung Dalam: IMLA, 2007, h. 64-45

${ }^{5}$ M Soenardi Djiwandono, Tes Bahasa Dalam Pengajaran, Bandung: ITB, 1996,.h. 68 
juga dipelajari oleh pengajar, sehingga keterampilan berbicara dianggap bagian yang sangat mendasar dalam mempelajari bahasa asing. ${ }^{6}$

Ada beberapa unsur yang mempengaruhi siswa untuk menguasai kemahiran ini, diantaranya kemampuan guru, latar belakang siswa, metode pengajaran, dan media pengajaran. Semua itu harus menjadi perhatian yang serius bagi pendidik dan pemerhati bahasa khususnya bahasa yang akan diajarkan sehingga tujuan dari pembelajaran dan pengajaran bahasa dapat tercapai.

Latar belakang peserta didik merupakan hal yang sangat dominan dalam mempengaruhi pembelajaran kalam. Kesalahan-kesalahan yang biasanya terjadi dalam pembelajaran kemahiran kalam adalah adanya perbedaan karakter bahasa Arab dan bahasa ibu atau bahasa Indonesia. Dalam berbicara menggunakan bahasa Arab, biasanya siswa terkontaminasi atau disebut dengan ter interferensi dengan bahasa ibunya, padahal pola yang ada dalam bahasa Arab dan bahasa ibu peseerta didik itu berbeda. Seperti ketika mengatakan "sekolah ini”, seharusnya peserta didik mengatakan هذه مدرسة akan tetapi mereka mengatakan مدرسة هذه

Banyak aspek interferensi yang terjadi ketika siswa belajar bahasa Arab khususnya kemahiran berbicara. Siswa tidak akan merasa bahwa yang dilakukan itu keliru, karena diakibatkan kebiasaan yang ia lakukan pada bahasa sebelumnya. Oleh karena itu, guru harus peka terhadap peristiwa ini sehingga dapat mengingatkan terhadap siswanya untuk meminimalisir terjadinya interferensi.

Berkaitan dengan inteerferensi, banyak mahasiswa PBA yang masih mengalami hal tersebut, ketika berbicara dengan bahasa Arab, mereka masih mencampur antara bahasa ibu dengan bahasa Arab. Dari adanya fenomena ini,

\footnotetext{
${ }^{6}$ Abd. Wahab Rosyidi \& Mamlu'atul Ni'mah, Memahami Konsep Dasar Pembelajaran Bahasa Arab, Malang: UIN-Maliki Press, 2011, h. 88
} 
peneliti ingin mencoba menggali melalui peneitian ini tentang adanya fenomena interfernsi yang terjadi di tengah mahasiswa bahasa Arab di STAIN Curup.

Adapun rumusan masalah yang ada yaitu:

1. Apakah macam-macam Interferensi yang terjadi dalam pembelajaran maharah al kalam bagi mahasiswa PBA?

2. Faktor apa yang mengakibatkan terjadinya interferensi bahasa Indonesia ke dalam pembelajaran maharah al kalam bagi mahasiswa PBA?

Adapun jenis penelitian yang peneliti lakukan guna mengungkapkan fakta terkait masalah interferensi pembelajaran kemahiran berbicara bahasa Arab adalah penelitian field research (penelitian lapangan). ${ }^{7}$ Di samping itu, penelitian ini juga menggunakan satu pendekatan yaitu pendekatan kualitatif. Menurut Bogdan dan Taylor (1975:5) penelitian kualitatif yaitu prosedur penelitian yang menghasilkan data deskriptif, dimana data yang dikumpulkan berupa kata-kata tertulis atau lisan dari orang-orang dan perilaku yang dapat diamati.

Di samping itu, populasi dan sampel adalah bagian penting dalam peneleitian. Populasi yang menjadi subyek penelitian ini adalah mahasiswa semester 3 dan 5 yang jumlahnya kurang dari 100 orang sehingga populasi itu juga menjadi sampel dalam penelitian ini.

Subyek penelitian yang ada menjadi sumber data yang utama dalam mencari informasi yang berkaitan dengan interferensi. Penelitian menggunakan beberapa teknik dalam mengumpulkan data, yaitu:

7 Case study research and field study research (Penelitian kasus dan penelitian lapangan) adalah penelitian yang bermaksud mempelajari secara intensif tentang latar belakang keadaan sekarang dan interaksi suatu sosial, individu, kelompok, lembaga dan masyarakat. Husaini Usman dan Purnomo Setiady Akbar. 2003. Metodologi Penelitian Sosial, Jakarta: PT Bumi Aksara, h. 5. 


\section{Observasi}

Pengamatan terlibat (participant observation) yaitu pengamatan langsung pada obyek penelitian tanpa intervensi eksistensinya dan terjadi interaksi antara peneliti dan informan. Obsevasi ini dilakukan untuk memperoleh data factual dalam bentuk berbagai kegiatan yang terkaitan pembelajaran kemahiran berbicara bahasa Arab

\section{Wawancara}

Peneliti melakukan wawancara mengunakan teknik wawancara tak tersetuktur. ${ }^{8}$ Teknik ini peneliti pilih karena lebih bersifat luwes atau lentur dan dirancang agar sesuai dengan subjek dan suasana pada wawancara berlangsung

\section{Dokummentasi}

Teknik dokumentasi peneliti lakukan dengan cara mengumpulkan dokumen-dokumen dan literatur yang memiliki keterkaitan dengan persoalan interferensi bahasa ibu terhadap bahasa Arab khusunya dalam kemahiran berbcara.

Adapun teknik analisa data yang digunakan adalah analisa kualitatif ${ }^{9}$ dengan pola berfikir induktif. Analisa induktif yang dimaksud adalah analisa yang berangkat dari data yang bersifat khusus kemudian ditarik kesimpulannya yang bersifat umum. Setelah data terkumpul, maka data

8 Teknik wawancara terbagi menjadi dua macam, wawancara berstruktur dan wawancara tak tersetuktur. Dalam wawancara berstruktur pertanyaan dan alternatif jawaban yang diberikan kepada interviewee telah ditetapkan terlebih dahulu, sedangkan pada pada wawancara tak terstruktur pertanyaan-pertanyaan dapat diajukan secara bebas kepada subjek. Suharsimi Arikunto, Prosedur Penelitian Suatu Pendekatan Praktek, Jakarta: Rineka Cipta, 1993, h. 180.

${ }^{9}$ Analisa kualitatif artinya menguraikan data secara bermutu dalam bentuk kalimat yang teratur, runtun, logis, tidak tumpang tindih, dan efektif sehingga memudahkan pemahaman dan interpretasi data, Abdul Kadir Muahammad. 2004. Hukum dan Penelitian Hukum, PT. Citra Aditya Bhakti, Jakartah. H. 172 
tersebut dianalisis untuk mendapatkan konklusi. Adapaun metode yang penulis gunakan untuk menganalisis data adalah:

1. reduksi data

2. penyajian data

3. Conclusion Drawing

Di samping itu, data yang sudah diperoleh dan dianalisis dicek kembalinya kebenarannya melalui:

1. Perpanjangan kehadiran peneliti

2. Ketekunan pengamatan

3. Triangulasi

pemeriksaan keabsahan data yang memanfaatkan sesuatu yang lain diluar data untuk keperluan pengecekan atau sebagai perbandingan terhadap data. Data yang telah diperoleh melalui pengamatan diperiksa kembali melalui wawancara dengan subyek penelitian sehingga akan diketahui apakah data itu sama atau justru malah berbeda dengan data yang sudah diperoleh.

\section{B. Pembahasan}

interferensi pertama kali digunakan oleh Weinreich untuk menyebutkan adanya perubahan sistem suatu bahasa sehubungan dengan adanya persentuhan bahasa tersebut dengan unsur-unsur bahasa lain yang dilakukan oleh penutur dua bahasa. ${ }^{10}$

Hartman \& Stork mengatakan bahwa interferensi sebagai "kekeliruan" yang disebabkan oleh terbawanya kebiasaan-kebiasaan ujaran bahasa atau dialek ibu ke dalam bahasa atau dialek kedua. ${ }^{11}$ Dalam hal initente orang yang mempelajari bahasa kedua atau bahasa Arab misalnya akan mengalami

\footnotetext{
${ }^{10}$ Abdul Chaer dan Leoni Agustina, Sosiolinguistik Perkenalan Awal, Jakarta: Rineka Cipta, h. 120, 1995

${ }^{11}$ A Chaedar Alwasilah, Beberapa Madhab dan dikotomi Teori Linguistik. Bandung: Angkasa, 1985, h 131
} 
kekliruan yang seharusnya itu menjadi benar bila dugunakan dalam bahasa pertama.

Nababan menyebutkan bahwa interferensi sebagai suatu "pengacauan" yang terjadi pada penutur dua bahasa yang disebabkan karena penguasaan bahasa yang tidak seimbang. Penguasaan bahasa yang tidak seimbang dapat terjadi pada kemajemukan bilingual. Kemajemukan ini terjadi karena pemahaman terhadap dua bahasa tidak seimbang sehingga salah satu lebih dominan meskipun yang digunakan adalah bahasa yang lain. ${ }^{12}$ Kebiasaan bahasa pertama yang mempengaruhi bahasa kedua tersebut yang dinamakan pengacauan oleh Nababan

Dalam kaitannya bahasa Arab, Abdul Aziz al Ashili menjelaskan bahwa interferensi adalah perpindahan seorang peserta didik dari satu sistem bahasa ibu atau kaidahnya ke dalam bahasa kedua baik ketika berbicara maupun menulis. Percampuran dua bahasa yang terjadi dapat mengganggu pembelajaran bahasa kedua. ${ }^{13}$

Definisi interferensi yang dikemukakan oleh beberapa ahli bahasa, dapat disimpulkan dengan adanya kesamaan yang menyebutkan bahwa interferensi adalah terjajdinya percampuran dua bahasa yang digunakan oleh seseorang dan dapat mengganggu dan mengacaukan pembelajaran bahasa

\section{Macam-macam interferensi}

Seperti halnya diketahui, bahwa interferensi terjadi karena adanya pemahaman yang dominan terhadap satu bahasa. Interferensi ini terjadi bukan hanya dalam menulis akan tetapi juga terjadi dalam kemahiran berbicara. Interferensi terbagi menjadi beberapa macam yaitu:

a) Interferensi kultural, hal ini dapat terjadi melalui bahasa yang digunakan oleh pengguna dua bahasa. Dalam bahasa Arab

\footnotetext{
${ }^{12}$ Nababan, Sosiolingistik, suatu pengantar, Jakarta: Grafindo, 1991, h. 33

${ }^{13}$ M. Afifudin Dimyati, Muhadhoroh fi Ilmi Lughah al Ijtima'I, Surabaya: Dar al Ulum al Arabiyah, 2010, h. 101
} 
interferensi ini biasanya terjadi diakibatkan kurang tahunya pelajar bahasa sehingga kultur yang muncul dalam penggunaan bahasa Arab masih kultur bahasa pertama. Mereka mengatakan فات القطار, dengan makna yang diinginkan yaitu "ketinggalan kereta" padahal dalam bahasa Arab -secara budaya- istilah ini tidak dikenal, ungkapan yang dikenal yaitu قد سبق السيف العذل

b) Interferensi leksikal, yaitu masuknya unsur leksikal bahasa pertama ke dalam bahasa kedua. Interferensi ini terjadi dalam bahasa Arab baik dalam isim, fiil, sifat, huruf, isim dhomir, nakiroh dan makrifatnya. ${ }^{14}$ Contoh interferensi jenis ini هبت إلى المدرسة موطور, kosa kata yang bergaris bawah terlihat dan terdengar seperti bahasa Arab, padahal itu adalah bahasa Indonesia yang masuk kedalam ungkapan bahasa Arab

c) Interferensi semantic, interferensi ini terjadi dalam penggunaan kata yang mempunyai variabel dalam suatu bahasa. Contoh dari interferensi ini yaitu ungkapan yang sering digunakan oleh siswa yang belajar bahasa Arab dalam menyebutkan sekolah MTs, مدرسة الثانوية mereka mengatakan

d) Interferensi sintaksis, interferensi ini meliputi sistem gramatikal atau sintaksis bahasa Arab yang digunakan oleh siswa akan tetapi tata bahasa yang digunakan bercampur dengan tata bahasa pertama. Seperti kata الطالبان ماهر, ungkapan dalam bahasa Arab harus harus ada kesesuaian kata, baik dari bentuk tunggalnya, dobelnya, maupun pluralnya.

e) Interferensi morfologi, yaitu interferensi yang terjadi pada pembentukan dan perubahan bentuk kata (sharf). Contoh dari

\footnotetext{
${ }^{14}$ M. Afifudin Dimyati, Istikhdam al Mufradat al Arabiyah al Muqtaridhah fi lughah al Indonisiyah $f i$ Ta 'lim Nushus al Mawad at Ta 'limiyah, al Khurthum, Disertasi, 2007, h. 80
} 
interferensi ini yaitu ungkapan, اثنين كتاب, yang berarti dua kitab. Padahal bentuk doble dalam bahasa Arab cukup menambahkan alif dan nun atau ya' dan nun dari bentuk tunggalnya yang biasa juga disebut tasniyah.

f) Interferensi fonologis, Interferensi fonologis merupakan interferensi pada pengucapan atau lafal, Seperti halnya kata شديد, yang diucapakan dengan syin tipis yakni سديد. Makna dari kata tersebut tentu berubah, kata yang pertama bermakna "keras" dan yang kedua bermakna "halus".

g) Interferensi paralinguistic, yaitu gerakan atau isyarat yang digunakan oleh pengguna bahasa akan tetapi tidak dikenal dalam bahasa kedua. ${ }^{15}$

\section{Faktor-Faktor Terjadinya Interferensi}

Interferensi merupakan kenyataan yang terjadi dalam pembelajaran bahasa. Ada beberapa faktor yang menyebabkan terjadinya interferensi, di antara factor yang menyebabkan munculnya interferensi yaitu:

a) Kedwibahasaan peserta tutur

Kedwibahasaan peserta tutur merupakan sebab pokok terjadinya interferensi serta aneka pengaruh yang lain dari bahasa sumber, baik dari bahasa daerah maupun bahasa asing.

b) Tidak cukupnya kosakata bahasa penerima

Keterbatasan kosa-kata yang akan digunakan oleh seseorang dalam mengungkapkan konsep terbaru tersebut yang membuatnya terpaksa menggunakan kosa kata bahasa ibu atau sumber, baik hal itu dirasa disengaja maupun tidak. Faktor kurangnya dan terbatasnya kosa-kata bagi seorang penutur dwibahasa inilah yang mengakibatkan ia mengungkapkan suatu konsep baru dalam

${ }^{15}$ M. Afifudin Dimyati, Muhadhoroh fi Ilmi Lughah al Ijtima'I, h. 109 
bahasa sumber serta menjadikannya cenderung untuk menimbulkan terjadinya interferensi. Interferensi yang diakibatkan oleh kebutuhan kosakata baru, cenderung dilakukan secara sengaja oleh pemakai bahasa.

c) Tipisnya kesetiaan pemakai bahasa penerima Tipisnya kesetiaan pengguna dua bahasa terhadap bahasa penerima cenderung akan menimbulkan sikap yang agak negatif. Hal itu mengakibatkan ketidak perdulian terhadap kaidah bahasa ke dua yang digunakan dan unsur-unsur yang dikuasai dalam bahasa sumber diambil oleh penutur secara tidak terkontrol.

d) Menghilangnya kata-kata yang jarang digunakan Interferensi yang disebabkan oleh menghilangnya kosakata yang jarang digunakan tersebut akan berakibat seperti interferensi yang disebabkan kurangnya kosakata bahasa pengguna bahasa, yaitu unsur serapan atau unsur pinjaman akan lebih cepat diintegrasikan karena bahasa penerima sangat membutuhkan unsur tersebut.

e) Terbawanya kebiasaan dalam bahasa ibu

Kebiasaan yang terbawa dalam bahasa ibu pada bahasa kedua yang sedang digunakan, pada umumnya terjadi karena kurangnya kontrol bahasa dan kurangnya penguasaan terhadap bahasa kedua. Hal ini dapat terjadi pada sesorang yang sedang belajar bahasa kedua, baik bahasa nasional maupun bahasa asing.

f) Prestise bahasa sumber dapat mendorong timbulnya interferensi, karena pemakai bahasa ingin menunjukkan bahwa dirinya dapat menguasai bahasa yang dianggap memiliki prestise yang tinggi tersebut. 


\section{Maharah al Kalam}

Kalau kita berbicara tentang bahasa, kemahiran kalam merupakan bagian dari keterampilan berbahasa. Kemahiran kalam adalah kemampuan seseorang dalam mengucapkan bunyi artikulasi dan kata-kata untuk mengekspresikan ide, pikiran, keinginan ke lawan bicaranya. Dalam arti yang lebih luas, berbicara merupakan sistem tanda-tanda yang dapat didengar melalui bagian organ tertentu untuk menyampaikan keinginan seseorang. ${ }^{16}$

Kemahiran berbicara dalam bahasa khususnya bahasa Arab sangat penting jika dibandingkan dengan kemahiran yang lain. Hal ini sesuai dengan apa yang disampaikan oleh Acep Hermawan bahwa kemahiran berbicara menjadi lebih penting, karena menggunakan bahasa dalam berbicara benarbenar mencerminkan suatu bahasa. ${ }^{17}$ Oleh karena itu menjadi penting bagi setiap orang yang belajar bahasa untuk dapat menguasai kemahiran ini.

Keterampilan berbicara adalah keterampilan yang paling penting dalam bebahasa. Sebab berbicara adalah bagian dari keterampilan yang dipelajari oleh pengajar, sehingga keterampilan berbicara dianggap sebagai bagian yang sangat mendasar dalam mempelajari bahasa asing. ${ }^{18}$

Ada beberapa faktor yang dapat menunjang kemampuan berbicara bahasa Arab seseorang dapat berkembang, pertama penguasaan mufradat. Kedua, keberanian untuk mengucapkan meskipun salah. Ketiga, teman atau lingkungan bahasa. Kedudukan bieah lughawiyah sangat membantu keberhasilan kalam. Karena kalam memmbutuhkan teman atau lawan bicara. Hal ini sesuai dengan apa yang tertulis dalam muqaddimah Al-Arabiyah LiAnnasyiin juz 2 dan $3 .{ }^{19}$

\footnotetext{
${ }^{16}$ Acep Hermawan, Metodologi Pembalajaran Bahasa Arab, Bandung: PT Remaja Rosdakarya, 2011, h. 135

17 Ibid, h. 130

${ }^{18} \mathrm{Abd}$. Wahab Rosyidi \& Mamlu'atul Ni'mah, h. 88

${ }^{19}$ Bahwasanya pembelajaran bahasa akan mengalami kemajuan apabila dilakukan secara terus menerus dan dipraktikkan dalam berkomunikasi antara seorang guru dengan 


\section{Hasil Penelitian}

Dari pengamatan dan dokumentasi yang peneliti lakukan, peneliti menemukan beberapa contoh ungkapan yang mengandung adanya unsur interferensi yang dilakukan oleh mahasiswa ketika mereka berbicara bahasa Arab:

1. Pada contoh pertama, ada mahasiswa yang mengatakan “ نظرت المدرسة هناك". Ungkapan ini bermakna "saya melihat sekolah". Ketika kita melihat secara cermat ungkapan bahasa Arab tersebut dari sisi keilmuan bahasa Arab. Kita menemukan kata kerja dalam bahasa Arab tidak seluruhnya bisa bergandengan langsung dengan obyeknya melainkan membutuhkan terhadap kalimat yang lain dulu.

Pada kalimat di atas yaitu kata kerja "melihat" yang dalam bahasa Arab disebut dengan نظر tidak dapat bertemu dengan obyeknya secara langsung, kata ini membutuhkan kata lain sebagai sambungan dengan obyeknya yaitu kata إلى Oleh karena itu menjadi keliru ketika kata kerja ini digunakan dalam sebuah ungkapan seperti di atas.

Kesalahan ini diakibatkan karena dalam bahasa yang sering digunakan oleh mahasiswa tidak mengenal adanya kaidah yang memisah antara kata kerja dan objeknya seperti halnya yang ada di dalam bahasa Arab. Pengaruh bahasa satu ke dalam bahasa lain yang menimbulkan kekeliruan inilah yang disebut dengan interferensi. Interferensi yang terjadi disebabkan oleh penyesuaian kata sambung seperti ini disebut dengan interferensi semantic.

siswanya begitu juga siswa dengan teman-temannya yang secara tidak langsung akan membentuk lingkungan kebahasaan yang bagus dan akan mempersiapkan tempat lingkungan yang baik dan subur untuk bahasa serta membutuhkan waktu yang mencukupi 
2. Adapun pada ungkapan selanjutnya, mahasiswa mengatakan " أريد أذهب إلى السوق ", dengan makna yang dimaksud “saya ingin pergi ke pasar."

Kita akan menemukan bahwa dalam aturan dan tata kaidah bahasa Arab tidak memperbolehkan adanya pertemuan dua kata kerja secara langsung dan kata kerja kedua sebagai obyeknya. Namun ketika kita melihat dari bahasa Indonesia itu sah dan benar. Bahasa Indonesia tidak mengenal adanya kaidah tersebut.

Kata kerja dalam bahasa Arab bisa dijadikan obyek ketika dirubah menjadi masdar muawal. Perubahan kata kerja ini dengan cara atau rumus "أن + فعل مضار ع". Di samping itu, jika menemui kondisi kalimat seperti ungkapan di atas maka diperbolehkan juga mengganti kata kerja yang menjadi obyek dengan betuk masdarnya sehingga dapat diterima dan dibenarkan menurut tata kaidah bahasa Arab.

Dengan demikian ungkapan yang harus diucapkan oleh mahasiswa yaitu أريد أريد الذهاب إلى السوق Katau. Kesalahan yang ada dalam ungkapan di atas termasuk dalam kategori interferensi sintaksis.

3. Pada kalimat selanjutnya kita menemukan ungkapan mahasiswa yang berbunyi “في الفصل هذا نحن نتعلم". Kita akan menemukan bahwa tujuan yang diinginkan adalah "di kelas ini kita belajar". Ketika kita mengambil satu kalimat dari contoh tersebut yaitu "kelas ini" maka kita akan menemukan bahwa ada kekliruan dalam peralihan bahasa dari bahasa Indonesia ke bahasa Arab. Sebagaiman kita ketahui bahwa pada penggunaan kata tunjuk dalam bahasa Indonesia itu harus mendahulukan benda yang ditunjuk dan kemudian menyebutkan kata tunjuknya, berbeda dengan bahasa Arab, kata tunjuk justru harus disebutkan terlebih dahulu dari obyek yang ditunjuknya. Dengan 
demikian, kita menemukan kekeliruan pada ungkapan mahasiswa di atas yang terletak pada kalimat "الفصل هذا". Kalimat ini seharusnya mendahulukan kata tunjuknya sesuai dengan aturan yang ada dalam bahasa Arab berkaitan dengan kata tunjuk yang disebut dengan isim isyarah.

Oleh karena itu seharusnya kalimat di atas berbunyi "في هذا الفصل نتعلم". Pengaruh dari bahasa satu ke bahasa yang lain semacam inilah yang disebut dengan interferensi. Adapun interferensi yang terjadi pada ungkapan di atas termasuk dalam kategori interferensi sintaksis atau nahwu

4. Pada kalimat selanjutnya, dijumpai mahasiswa yang mengatakan "Dari segi maknanya, bisa dipahami bahwa “ia shalat di masjid bersama laki-laki." Ungkapan ini adalah hasil dari penerjemahan secara tekstual bahkan kalimat perkalimat sehingga tidak menghiraukan terhadap kaidah bahasa Arab yang berlaku.

Bahasa Arab memiliki cara yang khusus dalam membuat betuk banyak dari satu kalimat. Dengan demikian, Kekeliruan yang terdapat pada ungkapan mahasiswa di atas terletak di ujung kalimat yakni pengulangan kata “رجل". Padahal, yang terpenting dalam pemindahan bahasa, baik dari bahasa Arab-Indonesia maupun sebaliknya, harus mengikuti kaidah dan aturan bahasa yang akan dituju dan digunakan. Seharusnya mahasiswa merubah kata "رجل" menjadi bentuk jamaknya bukan justru mengulangnya yaitu "رجال", yang termasuk dari jenis jamak taksir. Oleh sebab itu kalimat yang seharusnya diucapkan adalah “أصلي في المسجد مع رجل".

Dengan demikian, kesalahan yang ada pada ungkapan ini termasuk dalam interferensi sintaksis. 
5. Pada ungkapan selanjutnya kita menjumpai kalimat yang digunakan oelh mahasiswayaitu “فاطمة يكتب الرسالة إلى صديقها". Arti kalimat di atas dalam bahasa Indonesia yaitu "Fatimah menulis surat kepada temannya". Bahasa Indonesia -sebagaimana diketahui- tidak mengenal akan perubahan kata kerja dalam kondisi dan waktu apapun. Kata kerja dalam ungkapan bahasa Indonesia akan selalu tetap meskipun waktu maupun subyeknya berubah berbeda ketika kita melihat dalam bahasa Arab. Bahasa Arab sangat detail dalam menentukan dan menyesuaikan subyek dengan predikatnya. Ketika subyek dalam suatu pekerjaan itu perempuan maka kata kerja yang digunakan juga harus kata kerja yang mengandung kata ganti perempuan, begitu juga penyesuaian dengan waktunya.

Oleh karena itu, dalam ungkapan di atas subyeknya adalah perempuan, mahasiswa tidak merubah kata kerja yang ada pada kalimat tersebut, kalimat tersebut justru malah menagandung kata ganti laki-laki “يكتب". Seharusnaya kata ini berubah menyesuaikan subyeknya menjadi فاطمة تكتب الرسالة إلى “"كتب"، sehingga ungkapan itu berubah menjadi", صديقه".

Dengan demikian maka terjadilah interferensi pada ungkapan ini yang mengakibatkan kesalahan dalam perubahan kata kerja. Interferensi yang terjadi pada ungkapan ini adalah interferensi morfologi.

6. Adapun pada ungkapan selanjutnya, mahasiswa ada yang mengatakan . وهذا الطعام لا محبوب Ungkapan ini bermakna "makanan ini tidak disukai". Jika melihat ungkapan di atas maka bisa dikatakan bahwa mahasiswa hanya memperhatikan pemindahan bahasa secara harfiah bukan maknawiyah. Oleh karena itu, kekeliruan yang terjadi pada

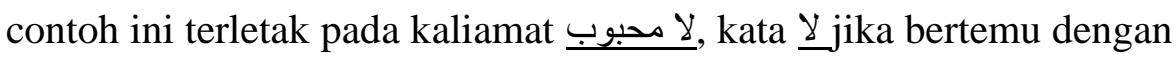
isim akan berbeda makna bila dibandingkan dengan $\underline{\vee}$ yang bertemu 


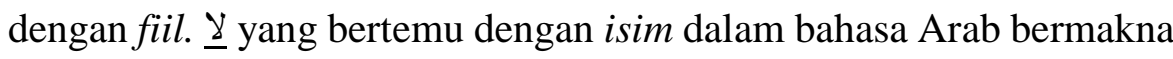
meniadakan jenis sesuatu dan $\underline{\vee}$ yang bertemu dengan fiil akan memiliki makna "tidak atau jangan".

Jika demikian, Kalimat tersebut menjadi bermakna "makanan ini tidak ada yang disukai", yaitu dengan meniadakan makanan yang disukai, padahal tujuan yang ingin diungkapkan adalah "tidak suka". Seharusnya ungkapannya dengan makna "tidak" yaitu "غير", sehingga kata tersebut menjadi هذا الطعام غير محبوب. Interferensi ini termasuk dalam interferensi semantik.

7. Pada kalimat berikutya, terdapat ungkapan “"أين إنسانه”". Kalimat ini bermakna “di mana orangnya?", Pada dasarnya kalimat tersebut sudah sesuai dengan arti yang ada dalam bahasa Indonesia. Akan tetapi, kalimat tersebut tidak umum digunakan dalam bahasa Arab. Bahasa Arab mengenal biasanya hanya menggunakan kata ganti dalam kasus tersebut, cukuplah ia katakana أين هو.

Dengan demikian, seperti diketahui bahwa kekeliruan penggunaan bahasa yang disebabkan pengaruh dari bahasa lain disebut dengan interferensi. Interferensi yang terjadi pada contoh di atas termasuk dalam interferensi semantic

8. Pada kalimat berikutnya “.... هذا صاحبي لو “, arti dari kalimat tersebut. “ini temanku loh. .". Konfirmasi ditemukan dalam bahasa Arab akan tetapi dengan aturan-aturan tertentu. Di samping itu, kata dalam ungkapan tersebut bukan berasal dari bahasa Arab melainkan dari bahasa Indonesia yang masuk dalam bahasa Arab saat mahasiswa sedang berbicara.

Adapun informasi dalam bahasa Arab bisa dikonfirmasi dengan beberapa cara yang secara umum disebut dengan taukid. Di antara cara yang biasa digunakan untuk menguatkan sebuah informasi dalam 
bahasa Arab yaitu dengan mengulang kata yang ingin dikonfirmasi. Degan demikian, ungkapan yang digunakan oleh mahasiswa untuk menyampaikan informasi bahwa "ini teman ku lo.." dalam bahasa Arab tidak dibenarkan.

Oleh karena itu, jika mahasiswa ingin mengonfirmasi suatu informasi dalam bahasa Arab maka sebaiknya ia menggunakan uslub taukid. Sehingga kalimat di atas menjadi “هذا صاحبي صاحبي" . Dari penjelasan ini maka telah terjadi interferensi, Interferensi itu adalah interferensi sintaksis dan interferensi leksikologi.

9. Pada kalimat berikutnya, ada ungkapan " "ثلاثة صورة" dengan makna “tiga gambar". Jika kita melihat dari aspek ilmu sintaksis bahasa Arab, kita akan menemukan kekeliruan. Angka dalam bahasa Arab akan berbeda-beda dalam penggunaannya dari segi mudzakar dan muanats nya sesuai dengan benda yang dihitung. Angka 3 sampai dengan Sembilan dalam bahasa Arab harus berlawanan dengan yang dihitung dari aspek mudzakar dan muanats nya. Betuk muanats ini dilihat dari bentuk tunggalnya bukan jamaknya. Kekeliruan semacam inilah yang disebut dengan interferensi sintaksis. Kaidah bilangan dalam bahasa Arab tidak cukup di situ, angka 3 sampai dengan 9 jika digunakan dalam sebuah kalimat yang menunjukan hitungan sesuatu atau $m a$ 'dud, maka $m a$ 'dudnya itu harus dibentuk dengan jamaknaya.

Dengan demikian, ungkapan bahasa Arab yang harus digunakan oleh mahasiswa untuk menyampaikan adanya "tiga gambar" yaitu “ ثلاث "صور "صورة" dan merubah bilangannya menjadi “ثَثلاث" sehingga antara bilangan dan terbilang saling berlawanan.

10. Pada kalimat berikutnya terdapat ungkapan “ . . . منذ منى", dengan tujuan kalimat pertanyaan "sejak kapan...". 
Ungkapan semacam ini asing dan tidak umum digunakan, karena ada pertemuan dua huruf jer secara langsung dalam satu kalimat. Oleh karena itu, kekeliruan yang muncul bukan terletak dalam pemindahan satu bahasa ke bahasa yang lain melainkan dalam memilih kata yang tepat dan umum digunakan.

Sehubungan dengan ungkapan di atas, maka seharusnya mahasiswa memikirkan terlebih dahulu jenis waktu yang diinginkan. Setelah menentukan waktu tersebut, barulah dapat menyampaikan pertanyaan terkait dengan kata tanya di atas. Dengan demikian kalimat tanya yang harus diucapkan yaitu “وقنذ أي ... sehingga dapat diterima oleh pengguna bahasa Arab secara umum.

Interferensi yang terjadi ungkapan di atas yaitu interferensi semantic.

11. Kalimat berikutnya berbunyi “المؤمنون الذين آمنوا إلى اللى". Kalimat ini bermakna bahwa mukminun adalah orang-orang yang percaya atau beriman kepada Allah.

Ketika kita melihat dari sisi idiomotik, ada yang asing dan tidak umum didengar dan digunakan. Idiom dikatakan dan dianggap sangat penting lebih dikarenakan satu kata bisa memiliki beberapa makna sesuai dengan kata yang digandengnya.

Berkaitan dengan ungkapan di atas, kata "أمن- يؤمن" yang memiliki makna iman dan percaya seharusnya digandengkan dengan kata setelahnya yang bersambung dengan "ب" sehingga kalimat tersebut menjadi “... آمن بـ", sehingga yang benar “ألمؤمنون الذين آمنوا بالله”"

Kekeliruan inilah yang disebut dengan interferensi, yaitu interferensi semantic.

12. Intonasi ketika mahasiswa berbicara bahasa Arab. Seperti ungkapan mahasiswa yang ditemukan yaitu “إلى أين انتـــngan memanjangkan huruf terakhir dan menekannya. Mahssiswa 
seharusnya mengikuti lahjat dan berusaha untuk dapat sesuai dengan native speaker dalam berbicara. Intonasi memiliki peranan yang sangat penting, Kalimat sama yang diucapkan dengan intonasi yang berbeda akan memunculkan makna yang berbeda.

Dalam al Quran ada ayat yang berbunyi “وما عند اله خير للأبرار". Ayat ini memiliki dua makna yang saling berlawanan sesuai dengan intonasinya. Makna yang dimaksud dari ayat tersebut adalah "sesuatu itu baik di sisi Allah bagi orang-orang yang baik". Tujuan ayat tersebut akan tersampaikan jika intonasi yang tinggi terletak pada kata

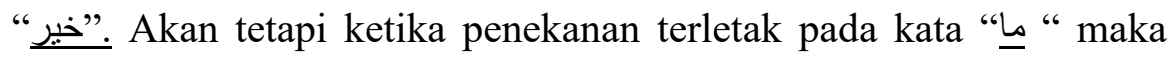
memiliki makana nafi sehingga ayat tersebut bermakna "tidak ada kebaikan di sisi Allah bagi orang-orang yang baik".

Adapun dengan intonasi pada ungkapan mahasiswa di atas, maka bisa dikatakan itu adalah bagian dari interferensi fonologi atau dalam bahasa Arab disebut dengan At Tadakhul As Shauti.

Untuk lebih mudahnya dalam memahami pemaparan data interferensi dan analisis di atas, dapat dilihat pada tabel di bawah ini:

\section{Tabel 1}

\section{Jenis-jenis interferensi bahasa Indonesia terhadap bahasa Arab}

\begin{tabular}{|c|c|c|c|c|}
\hline NO & $\begin{array}{l}\text { Ungkapan } \\
\text { Mahasiswa }\end{array}$ & $\begin{array}{c}\text { Kalimat } \\
\text { Interferensi }\end{array}$ & $\begin{array}{c}\text { Jenis } \\
\text { Interferensi }\end{array}$ & $\begin{array}{c}\text { Kalimat } \\
\text { yang benar }\end{array}$ \\
\hline 1 & نظرت المدرسة هناك & نظرت المدرسة & $\begin{array}{c}\text { Interferensi } \\
\text { semantik }\end{array}$ & نظرت إلى المدرسة \\
\hline 2 & أريد أذهب إلى السوق & أريد أذهب & $\begin{array}{c}\text { Interferensi } \\
\text { sintaksis }\end{array}$ & أريد أن أذهب/ الذهاب \\
\hline 3 & في الفصل هذا نحن نتعلم & في الفصل هذا & $\begin{array}{c}\text { Interferensi } \\
\text { sintaksis }\end{array}$ & في هذا الفصل \\
\hline
\end{tabular}




\begin{tabular}{|c|c|c|c|c|}
\hline 4 & رجل رجلي في المسجدمع & رجل رجل & $\begin{array}{c}\text { Interferensi } \\
\text { sintaksis }\end{array}$ & رجال \\
\hline 5 & فاطمة يكتب الرسالة إلى & فاطمة يكتب & $\begin{array}{c}\text { Interferensi } \\
\text { morfologi }\end{array}$ & فاطمة تكتب \\
\hline 6 & و هذا الطعام لا محبوب & لا محبوب & $\begin{array}{c}\text { Interferensi } \\
\text { semantik }\end{array}$ & غير محبوب \\
\hline 7 & أين إنسانه؟ & إنسانه؟ & $\begin{array}{c}\text { Interferensi } \\
\text { semantik }\end{array}$ & 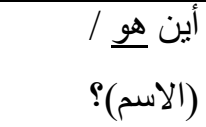 \\
\hline 8 & هذا صاحبي لو . . . & صاحبي لو. . & $\begin{array}{l}\text { Interferensi } \\
\text { sintaksis \& } \\
\text { interferensi } \\
\text { leksikologi }\end{array}$ & هذا صاحبي، \\
\hline 9 & ثلاثة صورة & ثلاثة صورة & $\begin{array}{c}\text { Interferensi } \\
\text { sintaksis }\end{array}$ & ثلاث صور \\
\hline 10 & منذ متى . . & منذ متى .. & $\begin{array}{c}\text { Interferensi } \\
\text { semantik }\end{array}$ & منذ أبي. \\
\hline 11 & الله المؤمنون الذين آمنو ا إلى & آمنو ا إلى الله & $\begin{array}{c}\text { Interferensi } \\
\text { semantik }\end{array}$ & آمنو ا بالله \\
\hline 12 & إلى أين انتــــــ & انتـــــ & $\begin{array}{c}\text { Interferensi } \\
\text { fonologi } \\
\text { (intonasi) }\end{array}$ & $\begin{array}{c}\text { Sesuaikan } \\
\text { dengan } \\
\text { bahasa } \\
\text { Arab }\end{array}$ \\
\hline
\end{tabular}




\section{Kesimpulan}

1. Interferensi bahasa Indonesia terhadap berbicara bahasa Arab bagi mahasiswa PBA terdiri dari beberapa jenis interferensi, yaitu: interferensi semantic, sintaksis, morfologi, leksikologi, dan fonologi.

2. Adapun faktor yang meyebabkan terjadinya interensi: dominasi bahasa Indonesia, kurangnya kosaa-kata bahasa Arab yang diketahui, dan kebiasaan bahasa Indonesia yang sudah sangat melekat sehingga susah ditinggalkan meskipun sudah berbicara dengan bahasa Arab.

\section{Daftar Pustaka}

Ahsanuddin, Mohammad, Pengembangan Keterampilan Berbicara dan Menulis Dengan Media Yahoo Messenger, Bandung Dalam: IMLA, 2007

Alwasilah, A Chaedar, Beberapa Madhab dan dikotomi Teori Linguistik. Bandung: Angkasa, 1985

Arikunto, Suharsimi Prosedur Penelitian Suatu Pendekatan Praktek, Jakarta: Rineka Cipta, 1993

Arsyad, Azhar, Bahasa Arab dan Pengajarannya, Yogyakarta: Pustaka Pelajar, 2010

Chaer, Abdul dan Leoni Agustina, Sosiolinguistik Perkenalan Awal, Jakarta: Rineka Cipta, 1995

Dimyati, M. Afifudin, Istikhdam al Mufradat al Arabiyah al Muqtaridhah fi lughah al Indonisiyah fi Ta'lim Nushus al Mawad at Ta'limiyah, al Khurthum, Disertasi, 2007

Dimyati, M. Afifudin, Muhadhoroh fi Ilmi Lughah al Ijtima'I, Surabaya: Dar al Ulum al Arabiyah, 2010 
Djiwandono, M Soenardi, Tes Bahasa Dalam Pengajaran, Bandung: ITB, 1996

Hermawan, Acep, Metodologi Pembalajaran Bahasa Arab, Bandung: PT Remaja Rosdakarya, 2011

HS, Moh. Matsna, Problematika pengajaran Bahasa Arab di Indonesia dan Pemecahannya, Makalah Seminar Pertemuan Ilmiah Bahasa Arab II di UGM, 2001

Muahammad, Abdul Kadir, Hukum dan Penelitian Hukum, Jakartah, PT. Citra Aditya Bhakti, 2004

Nababan, Sosiolingistik, suatu pengantar, Jakarta: Grafindo, 1991

Rosyidi, Abd. Wahab \& Mamlu'atul Ni'mah, Memahami Konsep Dasar Pembelajaran Bahasa Arab, Malang: UIN-Maliki Press, 2011

Sini, Ismail dkk,. al Arabiyah Li-Annasyiin, TP: Wizarotu Al-Maearif Mamlakah Al-,,Arabiyah As-sindiyahx, 2001

Usman, Husaini dan Purnomo Setiady Akbar, Metodologi Penelitian Sosial, Jakarta: PT Bumi Aksara, 2003 